\title{
HISTORY OF PATENTS
}

\author{
Ayu Agustin
}

Fakultas Komputer

448757212

Ayuagustin.student@umitra.ac.id

\begin{abstract}
A patent is a form of intellectual property. A patent gives its owner the right to exclude others from making, using, selling, and importing an invention for a limited period of time, usually twenty years. The patent rights are granted in exchange for an enabling public disclosure of the invention. People who are employed to do research are often obligated by their employment contracts to assign inventions to their employer. In most countries patent rights fall under civil law and the patent holder needs to sue someone infringing the patent in order to enforce their rights. In some industries patents are an essential form of competitive advantage; in others they are irrelevant.
\end{abstract}

The procedure for granting patents, requirements placed on the patentee, and the extent of the exclusive rights vary widely between countries according to national laws and international agreements. Typically, however, a granted patent application must include one or more claims that define the invention. A patent may include many claims, each of which defines a specific property right. These claims must meet relevant patentability requirements, such as novelty, usefulness, and non-obviousness.

Under the World Trade Organization's (WTO) TRIPS Agreement, patents should be available in WTO member states for any invention, in all fields of technology, provided they are new, involve an inventive step, and are capable of industrial application. ${ }^{[4]}$ Nevertheless, there are variations on what is patentable subject 
matter from country to country, also among WTO member states. TRIPS also provides that the term of protection available should be a minimum of twenty years.

Keyword : History Of Patents. 


\section{A. INTRODUCTION}

\section{- History :}

Although there is some evidence that some form of patent rights was recognized in Ancient Greece in the Greek city of Sybaris, ${ }^{[8][9]}$ the first statutory patent system is generally regarded to be the Venetian Patent Statute of 1474. Patents were systematically granted in Venice as of 1474 , where they issued a decree by which new and inventive devices had to be communicated to the Republic in order to obtain legal protection against potential infringers. The period of protection was 10 years. ${ }^{[10]}$. As Venetians emigrated, they sought similar patent protection in their new homes. This led to the diffusion of patent systems to other countries. ${ }^{[11]}$

The English patent system evolved from its early medieval origins into the first modern patent system that recognised intellectual property in order to stimulate invention; this was the crucial legal foundation upon which the Industrial Revolution could emerge and flourish. ${ }^{[12]}$ By the 16th century, the English Crown would habitually abuse the granting of letters patent for monopolies. ${ }^{[13]}$ After public outcry, King James I of England (VI of Scotland) was forced to revoke all existing monopolies and declare that they were only to be used for "projects of new invention". This was incorporated into the Statute of Monopolies (1624) in which Parliament restricted the Crown's power explicitly so that the King could only issue letters patent to the inventors or introducers of original inventions for a fixed number of years. The Statute became the foundation for later developments in patent law in England and elsewhere.

Important developments in patent law emerged during the 18th century through a slow process of judicial interpretation of the law. During the reign of Queen Anne, patent applications were required to supply a complete specification of the principles of operation of the invention for public access. ${ }^{[14]}$ Legal battles around the 1796 patent taken out by James Watt for his steam engine, established the principles that patents 
could be issued for improvements of an already existing machine and that ideas or principles without specific practical application could also legally be patented. ${ }^{[15]}$ Influenced by the philosophy of John Locke, the granting of patents began to be viewed as a form of intellectual property right, rather than simply the obtaining of economic privilege.

The English legal system became the foundation for patent law in countries with a common lawheritage, including the United States, New Zealand and Australia. In the Thirteen Colonies, inventors could obtain patents through petition to a given colony's legislature. In 1641, Samuel Winslow was granted the first patent in North America by the Massachusetts General Court for a new process for making salt. ${ }^{[16]}$

The modern French patent system was created during the Revolution in 1791. ${ }^{[18]}$ Patents were granted without examination since inventor's right was considered as a natural one. Patent costs were very high (from 500 to 1,500 francs). Importation patents protected new devices coming from foreign countries. The patent law was revised in 1844 - patent cost was lowered and importation patents were abolished.

The first Patent Act of the U.S. Congress was passed on April 10, 1790, titled "An Act to promote the progress of useful Arts". ${ }^{[19]}$ The first patent was granted on July 31, 1790 to Samuel Hopkins for a method of producing potash (potassium carbonate). A revised patent law was passed in 1793, and in 1836 a major revision to the patent law was passed. The 1836 law instituted a significantly more rigorous application process, including the establishment of an examination system. Between 1790 and 1836 about ten thousand patents were granted. By the Civil War about 80,000 patents had been granted

\section{B. CONCLUSION}

Although there is some evidence that some form of patent rights was recognized in Ancient Greece in the Greek city of Sybaris, ${ }^{[8][9]}$ the first statutory patent system is generally regarded to be the Venetian Patent 


\section{QUIZ Selected Section Class}

Statute of 1474. Patents were systematically granted in Venice as of

1474 , where they issued a decree by which new and inventive devices had to be communicated to the Republic in order to obtain legal protection against potential infringers. The period of protection was 10 years. ${ }^{[10]}$. As Venetians emigrated, they sought similar patent protection in their new homes. This led to the diffusion of patent systems to other countries.

\section{ACKNOWLEDGEMENT}

University Of Indonesia

University Of Mitra Indonesia

Telkom University

University Of Mellbourne

Saitama University

\section{REFERENCE (Based ISO 690 )}

A. S. Putra And O. M. Febriani, "Knowledge Management Online Application In Pdam Lampung Province," In Prosiding International Conference On Information Technology And Business
(Icitb), 2018, Pp. 181-187.

[2] A. S. Putra, O. M. Febriani, And B. Bachry, "Implementasi Genetic Fuzzy System Untuk Mengidentifikasi Hasil Curian Kendaraan Bermotor Di Polda Lampung," J. Sist. Inf. Dan Manaj. Basis Data, Vol. 1, No. 1, Pp. 21-30, 2018.

[3] O. M. Febriani And A. S. Putra, "Sistem Informasi Monitoring Inventori Barang Pada Balai Riset Standardisasi Industri Bandar Lampung," J. Inform., Vol. 13, No. 1, Pp. 90-98, 2014.

[4] Putra, Arie Setya. "2018 Artikel Struktur Data, Audit Dan Jaringan Komputer." (2018).

[5] Putra, A. S. (2018, July 17). Paperplain Fundamental Create Application With Borland Delphi 7.0 University Of Mitra Indonesia. Retrieved From Osf.Io/Pbrn9.

\section{E. REFERENCE (Based APA)}

Putra, A. S., Aryanti, D. R., \& Hartati, I. (2018, November). Metode SAW (Simple Additive Weighting) sebagai 
Sistem Pendukung Keputusan Guru Berprestasi (Studi Kasus: SMK Global Surya). In Prosiding Seminar Nasional Darmajaya (Vol. 1, No. 1, pp. 85-97).

Sari, D. P., Febriani, O. M., \& Putra, A. S. (2018, November). Perancangan Sistem Informasi SDM Berprestasi pada SD Global Surya. In Prosiding Seminar Nasional Darmajaya (Vol. 1, No. 1, pp. 289-294).

Putra, A. S. (2018). Paperplain: Execution Fundamental Create Application With Borland Delphi 7.0 University Of Mitra Indonesia.

Putra, A. S., Sukri, H., \& Zuhri, K. Sistem Monitoring Realtime Jaringan Irigasi Desa (JIDES) Dengan Konsep Jaringan Sensor Nirkabel. IJEIS (Indonesian Journal of Electronics and Instrumentation Systems), 8(2), 221232.

Darmawan, A., Yuliawati, D., Marcella, O., \& Firmandala, R. (2016). Sistem Absensi dan Pelaporan Berbasis Fingerprint dan SMS Gateway. EXPLORE, 7(1).
Febriani, O. M., Wahyuni, T., \& Yusuf, S. (2017). DESIGN OF WEBSITE-BASED INFORMATION SYSTEM FOR EDOCUMENT ADMINISTRASI IN THE COMMUNITY SERVICE UNIT (A Case Study at Rajabasa District). INTERNATIONAL JOURNAL OF COMPUTERS \& TECHNOLOGY, 16(7), 7010-7020.

Febriani, O. M., \& Wahyuni, T. (2017, October). PERANCANGAN SISTEM E-DOCUMENT ADMINISTRASI LOGBOOK PENELITIAN PADA UNIT LAYANAN DI BANDAR LAMPUNG. In Prosiding Seminar Nasional Darmajaya (Vol. 1, No. 1, pp. 187-194).

Febriani, O. M., \& Permadi, A. B. (2017). Implementasi Sistem Aplikasi Data Bimbingan dan Pelanggaran Siswa pada Sekolah Menengah Atas di Lampung Tengah dengan Metode Analisis dan Desain Sistem Terdistribusi (SSAD). EXPERT, 7(1). 
Febriani, O. M., \& Ambarwati, L. (2015). PERANCANGAN APLIKASI PENGOLAHAN DATA PENJUALAN UKM KELANTING KHAS TELO DESA SIDOHARJO KECAMATAN JATI AGUNG KABUPATEN LAMPUNG SELATAN. Jurnal Teknologi Informasi dan Bisnis Pengabdian Masyarakat Darmajaya, 1(1), 77-95.

Febriani, O. M. (2015). Rancang Bangun Aplikasi Ecommercemenggunakan Freewebstore pada UKM Kelanting di Desa Sidoharjo Lampung Selatan. Prosiding Sembistek 2014, 1(02), 446-458. 